\section{CAUSE FOR APPLAUSE}

Dentist Dr Greg Paysden, who runs a dental practice in North Manchester and another in Salford, ran the Wilmslow Half Marathon on 25 March 2012 to raise money for Smile Train. Formed in 1999, Smile Train is the world's leading cleft charity providing free cleft lip and palate surgery to children in developing countries. It also provides free cleft-related training for doctors and medica professionals. www.justgiving.com/GregPaysden

The Dental Wellness Trust (DWT) has begun working closely with the Amy Biehl Foundation. The Amy Bieh Foundation work with local communities in South Africa to improve the quality of life of underprivileged children affected by drugs, alcohol, violence and abuse. DWT's Dental Ambassador programme is joining the Amy Biehl Foundation's after school projects and public initiatives to educated disadvantaged children on oral self-care. www.dentalwellnesstrust.org

Dentaid is working with a team of Ugandan dentists, funding them to travel to rural villages to carry out general oral health education, sensitise communities on the dangers and prevention of infant oral mutilation, screen children and establish their oral health status, and to provide a pain-relief service of emergency extraction and atraumatic restorative treatment. Dentaid is keen to attract possible sponsors. Please visit www. justgiving.com/dentaid-barbara-uganda. Sponsors can be sent feedback on the dentist they have funded.

\title{
PROFESSIONAL SUPPORT UNIT LAUNCHED IN LONDON
}

On 17 April 2012 the London Deanery launched a new unit to support the professional development of doctors and dentists at all career stages and specialities working in the capital.

The Professional Support Unit led by London Deanery Provider Services will offer an expert shared service of resources, separate from employing organisations, to support the professional development of the medical and dental workforce in London. The unit will support clinicians as they develop as professionals and as individuals. It will help doctors and dentists throughout their careers, whether this is enabling them to meet the challenges offered by new roles, accessing coaching and personal development planning, or support with clinical placements and return to practice schemes.

London Deanery decided to launch the unit to respond to the need for better support to clinicians throughout their careers to enable them to realise and sustain their full potential, manage their talents and maximise their contribution to quality health care delivery.

Dr Julia Whiteman, Director of Appraisal Revalidation and Performance at London Deanery, said: 'Our stakeholders helped us identify the need for better support for clinicians as they progress through their careers from training to retirement and improved assessment processes for doctors and dentists in postgraduate training.'

A further function of the unit will be to do performance assessments to help put in place personal development plans from the results of appraisals to ensure doctors and dentists in London continue to develop their skills to the highest possible standards, delivering world class care for Londoners.

www.londondeanery.ac.uk/ professional-development/ professional-support-unit

\section{CHEEK TISSUE CELLS MUCH STRONGER THAN BONE MARROW CELLS}

Scientists at Cardiff University have created powerful new cells from cheek lining tissue which could offer the answers to disorders of the immune system.

While the body's immune system protects against many diseases, it can also be harmful. Using white blood cells (lymphocytes), the system can attack insulin-producing cells, causing diabetes, or cause the body to reject transplanted organs.

A team from Cardiff's School of Dentistry led by Professor Phil Stephens, with colleagues from Stockholm's Karolinska Institute, have found a new group of cells with a powerful ability to suppress the immune system's action.

The team took oral lining cells from the insides of patients' cheeks and cloned them. Laboratory tests showed that even small doses of the cells could completely inhibit the lymphocytes.

The breakthrough, which has been published online in Stem Cells and Development, ${ }^{1}$ suggests that the cheek cells have wide-ranging potential for future therapies for immune system-related diseases. Existing immune system research has focused on adult stem cells, particularly those derived from bone marrow. The cheek tissue cells are much stronger in their action.

'We have yet to recreate the effect outside the laboratory and any treatments will be many years away, said Dr Lindsay Davies, a member of the research team. 'However, these cells are extremely powerful and offer promise for combating a number of diseases. They are also easy to collect bone marrow stem cells require an invasive biopsy, whereas we just harvest a small biopsy from inside the mouth.'

The team has now been funded by the Medical Research Council to investigate the cloned cells further.

1. Davies L C, Lönnies H, Stephens P et al. Oral mucosal progenitor cells are potentially immunosuppressive in a dose-independent manner. Stem Cells Dev 2012; Epub ahead of print.

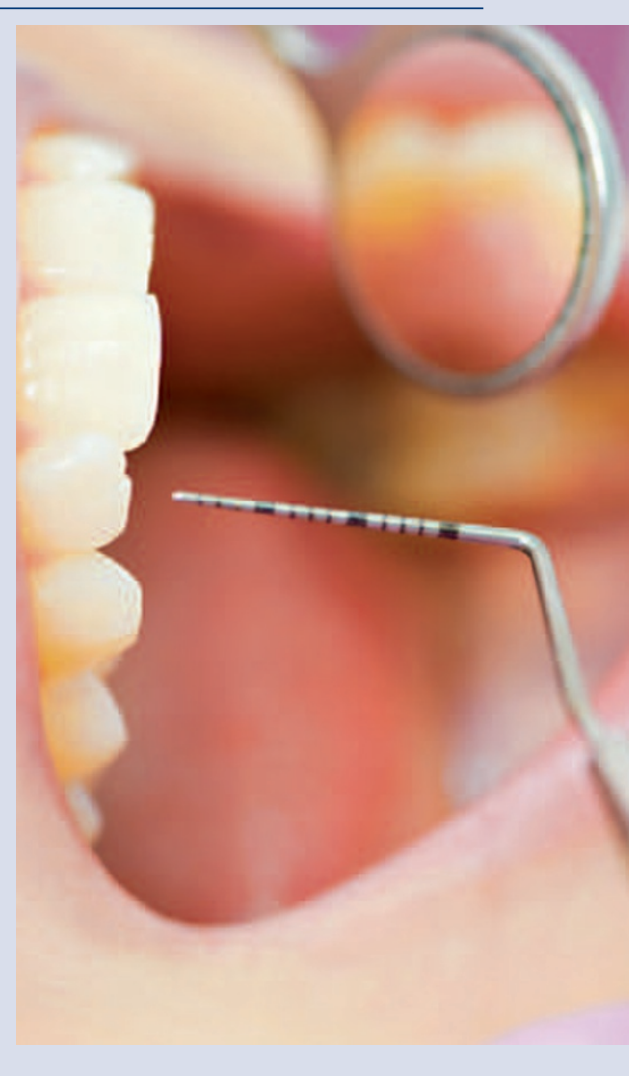

